\title{
Bacterial Profile and Antibiotic Susceptibility Pattern of Bacterial Keratitis at a Tertiary Hospital in Riyadh
}

This article was published in the following Dove Press journal:

Clinical Ophthalmology

\author{
Abdulrahman Almizel' \\ Fahad A Alsuhaibani' \\ Abdulrahman M Alkaff' \\ Ahmed S Alsaleh' \\ Samir M AL-Mansouri ${ }^{2}$ \\ 'College of Medicine, King Saud \\ University, Riyadh, Saudi Arabia; \\ ${ }^{2}$ Department of Ophthalmology, King \\ Saud University, Riyadh, Saudi Arabia
}

Background: The most common cause of ocular infections worldwide is bacteria; therefore, bacterial keratitis requires rapid and proper intervention because it is a major cause of loss of vision and ocular morbidity. Resistance studies have found increases in the resistance to ciprofloxacin, cefazolin, and gentamicin in bacterial keratitis cases that are caused by gram-positive organisms. Aim: To identify the common predisposing factors, causative organisms, and antibiotic profile of bacterial keratitis (BK) in a tertiary care hospital in Riyadh, Saudi Arabia.

Method: This is a retrospective study of the microbiological record of all patients diagnosed with BK at KAUH. From the first of May 2015 until the first of January 2018. Demographic data, diabetes mellitus, contact lens use, history of eye trauma, ocular surface disorders, recent ocular surgeries, current and recent medications, initial and final visual acuity, and location and size of the infiltrate were all used in the study. VA was converted to the logarithm of the minimum angle of resolution (LogMAR) for statistical analysis.

Results: 177 cases positive for BK were included. 100 (56.5\%) were males, and 77 (43.5\%) were females. The mean age was 43.15 . Trauma was the most common predisposing factor, which was observed in 68 (38.4\%) cases, followed by Ocular surface disease [52 (29.4\%)]. Staphylococcus epidermidis was the most commonly isolated organism [61 (34.5\%)], followed by Streptococcus pneumoniae [23 (13\%)], and Staphylococcus aureus [18 (10.2\%)]. All gram-positive cases were Vancomycin sensitive. Staphylococcus epidermidis showed only 4 resistant cases to chloramphenicol (7.27\%), and resistance to penicillin and ampicillin was found in $55(90 \%)$ and $53(89.83 \%)$ cases, respectively. All Streptococcus pneumoniae cases were resistant to gentamicin (100\%). Staphylococcus aureus showed high sensitivity for erythromycin [18 (100\%)].

Conclusion: The most common cause of bacterial keratitis was Staphylococcus epidermidis $(\mathrm{N}=61)$, followed by Streptococcus pneumoniae $(\mathrm{N}=23)$. Trauma was the most common predisposing factor $(38.4 \%)$, while contact lens use was only identified in 14 cases $(7.9 \%)$. All organisms tested were sensitive to vancomycin, and there was high resistance toward penicillin $(90 \%)$.

Keywords: keratitis, antibiotic, infection

\section{Introduction}

Bacterial keratitis is an infectious disease caused by a variety of bacterial strains that lead to inflammation of the cornea. It is a serious, sight-threatening condition that requires immediate intervention and proper treatment to prevent corneal scarring, perforation, and even blindness. ${ }^{1}$ It is reported that some highly virulent organisms showed corneal destruction at the first 24-48 $\mathrm{hrs}^{2}$ Bacterial keratitis is one of the most important causes of corneal opacification, which is the second most common cause of legal blindness worldwide. ${ }^{3}$
Correspondence: Abdulrahman Almize College of Medicine, King Saud University, Riyadh I 145I, Saudi Arabia

Email Amalmizel@gmail.com 
Staphylococcus aureus, Streptococcus pneumoniae, and Pseudomonas aeruginosa have been reported to be the leading etiological causes of bacterial keratitis. ${ }^{4}$ Coagulase-Negative Staphylococci (CoNS) have been increasingly documented as the cause of many ocular infections. ${ }^{5}$ Some of the common risk factors predisposing the cornea to infection are contact lens use, ocular surface disease, ocular trauma, and prior ocular surgery. ${ }^{6,7}$ Diagnosis of bacterial keratitis requires scraping of the cornea and culture growth to look for antibiotic sensitivity. While waiting for microbiological results, empirical therapy must be started immediately according to the clinical setting and the present microbiological spectrum and antibiotic sensitivity from the local data. ${ }^{8}$

Resistance studies have found increases in the resistance to ciprofloxacin, cefazolin, and gentamicin in bacterial keratitis cases that are caused by gram-positive organisms. ${ }^{8}$ Recent data are lacking regarding the bacterial profile and its antibiotic susceptibility pattern of bacterial keratitis in Saudi Arabia. Hence, this study aims to identify the causative organisms, predisposing factors, and antibiotic profile of bacterial keratitis in a tertiary care hospital in Riyadh, Saudi Arabia.

\section{Methodology Sampling}

We reviewed all cases diagnosed with bacterial keratitis from May 1, 2015, until January 1, 2018, at King Abdulaziz University Hospital. By using a computerbased diagnosis code of corneal scraping, all culturepositive cases of bacterial keratitis were selected. We excluded all subjects with non-bacterial, multiple isolate cultures.

\section{Data Collection}

177 cases with a positive culture were extracted from the microbiological records and reviewed. The following data were collected from the patient's' medical records: age, gender, diabetes mellitus, contact lens use, history of eye trauma, ocular diseases, recent ocular surgeries, current and recent medications, initial and final visual acuity (VA) (final VA was based on the last follow up), location and size of the infiltrate, presence of hypopyon, and complications. Details of the corneal cultures were collected, including the name of the organism and the suitability of the antibiotics used. VA was converted to the logarithm of the minimum angle of resolution (LogMAR) for statistical analysis.

\section{Statistical Analysis}

Categorical variables were summarized as numbers and percentages, and continuous variables were summarized with mean values. Paired t-tests were used to study the association between organisms and visual acuity as well as risk factors and visual acuity, where the mean visual acuity score was compared at the first and last visits. The analysis was performed using SAS/STAT software, version 9.2 (SAS Institute Inc., Cary, NC, USA.) and R foundation for statistical computing (Vienna, Austria). A 2-sided $\mathrm{p}$ value $<0.05$ was considered statistically significant.

\section{Results}

A total of 177 bacterial keratitis cases were included. Of the 177 cases, $100(56.5 \%)$ were males, and 77 (43.5\%) were females. The mean age of all included subjects was 43.15 years. The results of the cultures showed that the most common organisms were Staphylococcus epidermidis, Streptococcus pneumoniae, Staphylococcus aureus, Pseudomonas aeruginosa, and Staphylococcus hominis, representing $61(34.5 \%), 23(13 \%), 18(10.2 \%), 16$ (9.04\%), and $15(8.48 \%)$, respectively. Risk factors for bacterial keratitis were identified and are shown in Table 1. The most common predisposing factors for bacterial keratitis were trauma, ocular surface disease (OSD), diabetes mellitus (DM), surgery, and contact lens use with a total number of $68(38.4 \%), 52(29.4 \%), 40(22.6 \%), 39$ (22\%), and 14 (7.9\%) cases, respectively. Moraxella $\mathrm{sp}$ commonly occurs after trauma and was observed in 7 $(87.5 \%)$ cases. Moreover, Moraxella sp was the most commonly isolated organism after recent ocular surgery in 4 cases $(50 \%)$. Methicillin-resistant Staphylococcus aureus (MRSA) was the most frequently isolated organism with DM and OSD in 3 patients (75\%) and 2 patients (50\%), respectively (Table 1). Initial and final VAs in association with organisms are summarized in Table 2. We found that 55 out of 61 cases of Staphylococcus epidermidis were resistant to penicillin, while 53 were resistant to ampicillin. 19 out of 23 cases of Streptococcus pneumoniae were tested for gentamicin and were all resistant, while 12 cases $(54.55 \%)$ were resistant to penicillin (Table 3 ). The association between the risk factors and the visual outcomes is shown in Table 4. 
Table I Associations Between Organisms and Risk Factors of Bacterial Keratitis

\begin{tabular}{|c|c|c|c|c|c|c|c|c|}
\hline \multirow[t]{2}{*}{ Risk Factors } & \multicolumn{8}{|l|}{ Organism } \\
\hline & $\begin{array}{l}\text { Pseudomonas } \\
\text { aeruginosa } \\
\mathrm{N}=16\end{array}$ & $\begin{array}{l}\text { Staphylococcus } \\
\text { Epidermidis } \\
\mathrm{N}=61\end{array}$ & $\begin{array}{l}\text { Staphylococcus } \\
\text { aureus } \mathbf{N}=18\end{array}$ & $\begin{array}{l}\text { Streptococcus } \\
\text { pneumoniae } \\
\mathrm{N}=23\end{array}$ & $\begin{array}{l}\text { Moraxella } \\
\text { sp N=8 }\end{array}$ & $\begin{array}{l}\text { Staphylococcus } \\
\text { hominis } N=15\end{array}$ & $\begin{array}{l}\text { MRSA } \\
N=4\end{array}$ & $\begin{array}{l}\text { Others } \\
N=32\end{array}$ \\
\hline Contact lens & $3(18.75)$ & $6(9.84)$ & $3(16.67)$ & $0(0)$ & $0(0)$ & $0(0)$ & $0(0)$ & $2(6.25)$ \\
\hline Ocular surface disease & I (6.25) & $18(29.51)$ & $6(33.33)$ & $10(43.48)$ & $0(0)$ & $6(40)$ & $2(50)$ & $9(28.13)$ \\
\hline Recent ocular surgery & $2(12.5)$ & $10(16.39)$ & $3(16.67)$ & $9(39.13)$ & $4(50)$ & I (6.67) & I (25) & $9(28.13)$ \\
\hline Trauma & $4(25)$ & $17(27.87)$ & 7 (38.89) & $10(43.48)$ & $7(87.5)$ & $3(20)$ & I (25) & $\begin{array}{l}19 \\
(59.38)\end{array}$ \\
\hline Diabetes mellitus & $0(0)$ & $13(2|.3|)$ & $3(16.67)$ & $8(34.78)$ & $3(37.5)$ & $2(13.33)$ & $3(75)$ & $8(25)$ \\
\hline Topical steroid & $0(0)$ & $3(4.92)$ & $2(11.11)$ & $3(13.04)$ & $0(0)$ & $3(20)$ & $0(0)$ & $2(6.25)$ \\
\hline $\begin{array}{l}\text { Systemic } \\
\text { immunosuppression }\end{array}$ & I (6.25) & $0(0)$ & I (5.56) & $0(0)$ & $0(0)$ & $0(0)$ & $0(0)$ & $0(0)$ \\
\hline
\end{tabular}

\section{Discussion}

The most common cause of ocular infections worldwide is bacteria; ${ }^{9}$ therefore, bacterial keratitis requires rapid and proper intervention because it is a major cause of loss of vision and ocular morbidity. ${ }^{1}$ There is a broad discrepancy in the literature about the predisposing factors, visual outcomes, and resistance patterns of bacterial keratitis; therefore, recurrent studies are required to renew the present practice and guidelines.

Table 2 Associations Between Organisms and Visual Acuity (VA)

\begin{tabular}{|l|l|l|l|l|}
\hline Organism & Number & $\begin{array}{l}\text { VA First } \\
\text { Visit }\end{array}$ & $\begin{array}{l}\text { VA Last } \\
\text { Visit }\end{array}$ & P-value \\
\hline $\begin{array}{l}\text { Pseudomonas } \\
\text { aeruginosa }\end{array}$ & 3 & 0.45 & 0.10 & 0.500 \\
\hline $\begin{array}{l}\text { Staphylococcus } \\
\text { epidermidis }\end{array}$ & 22 & 1.50 & 1.47 & 0.907 \\
\hline $\begin{array}{l}\text { Staphylococcus } \\
\text { aureus }\end{array}$ & 7 & 1.76 & 0.94 & 0.093 \\
\hline $\begin{array}{l}\text { Streptococcus } \\
\text { pneumoniae }\end{array}$ & 12 & 1.85 & 1.81 & 0.718 \\
\hline Moraxella sp & 5 & 2.28 & 1.54 & 0.250 \\
\hline $\begin{array}{l}\text { Staphylococcus } \\
\text { hominis }\end{array}$ & 4 & 2.75 & 2.50 & 0.915 \\
\hline MRSA & 2 & 3.50 & 3.50 & - \\
\hline Others & 21 & 1.81 & 1.66 & 0.641 \\
\hline Overall & 76 & 1.78 & 1.58 & 0.076 \\
\hline
\end{tabular}

Our study revealed that bacterial keratitis is more common in males $(57 \%)$ than in their female counterparts with a mean age of 41 years. Conversely, a 2017 study conducted in Iran found that females are more susceptible to bacterial keratitis with a mean age of 22 years. This variation in results could be due to the high prevalence of contact lens use in their study, which are more widely used by the younger population. ${ }^{10}$ Our results show that the most commonly associated predisposing factor for bacterial keratitis was ocular trauma (38.4\%), which is consistent with previous studies done in a neighboring country. ${ }^{10,11}$ Moreover, ocular trauma has been the most common cause of corneal ulcer in low-income countries $(77.5 \%){ }^{12}$ Conversely, ocular trauma was found to be less common in some studies conducted in France and the UAE, ${ }^{12,13}$ which could be due to the difference in the socio-economic status. OSD was the second most commonly associated factor leading to bacterial keratitis (29.4\%), which seems to be high compared to other studies. However, this could be attributed to the high prevalence of OSD in Saudi Arabia, which was reported before by Bukhari A and colleagues. ${ }^{14}$ Contact lens usage was not a common cause of bacterial keratitis in our sample, which is similar to a previous study conducted in Egypt; ${ }^{3}$ however, other studies in Al-Qassim, Saudi Arabia, ${ }^{6}$ and Jordan $^{15}$ demonstrated that contact lens use is a common cause.

According to a study that was published in 2016 in Riyadh, Saudi Arabia, the most common causative organism of bacterial keratitis was Staphylococcus epidermidis, followed by Staphylococcus aureus and Streptococcus pneumoniae. ${ }^{16}$ Our study reveals similar findings with 
Table 3 Sensitivity and Resistance Against Most Common Causative Organisms of Bacterial Keratitis

\begin{tabular}{|c|c|c|c|c|c|c|c|c|c|c|}
\hline \multirow[b]{2}{*}{ Antibiotics } & \multirow[b]{2}{*}{ Level } & \multicolumn{9}{|c|}{ Organism } \\
\hline & & $\begin{array}{l}P s \\
N=16\end{array}$ & $\begin{array}{l}S e \\
N=6 I\end{array}$ & $\begin{array}{l}S a \\
N=18\end{array}$ & Sp $N=23$ & $M \times N=8$ & $S h N=15$ & $\begin{array}{l}\text { MRSA } \\
\mathrm{N}=4\end{array}$ & $\begin{array}{l}\text { Gp } \\
\mathbf{N}=\mathbf{2 0}\end{array}$ & $\begin{array}{l}\mathrm{Gn} \\
\mathrm{N}=12\end{array}$ \\
\hline Penicillin & $\mathrm{R}$ & $3(100 \%)$ & $\begin{array}{l}55 \\
(90.16 \%)\end{array}$ & $\begin{array}{l}15 \\
(83.33 \%)\end{array}$ & $\begin{array}{l}12 \\
(54.55 \%)\end{array}$ & I (50\%) & $\begin{array}{l}13 \\
(86.67 \%)\end{array}$ & $4(100 \%)$ & $\begin{array}{l}9 \\
(47.37 \%)\end{array}$ & $\begin{array}{l}5 \\
(71.43 \%)\end{array}$ \\
\hline Tobramycin & $\mathrm{R}$ & $0(0 \%)$ & I (100\%) & - & - & - & - & - & - & - \\
\hline Ceftazidime & $\mathrm{R}$ & $\begin{array}{l}\text { I } \\
(7.69 \%)\end{array}$ & - & - & $0(0 \%)$ & $0(0 \%)$ & - & - & $0(0 \%)$ & $0(0 \%)$ \\
\hline Ofloxacin & $\mathrm{R}$ & $0(0 \%)$ & $\begin{array}{l}7 \\
(13.46 \%)\end{array}$ & I (7.14\%) & I (5\%) & $0(0 \%)$ & $0(0 \%)$ & $0(0 \%)$ & $0(0 \%)$ & $\begin{array}{l}3 \\
(33.33 \%)\end{array}$ \\
\hline Gentamicin & $\mathrm{R}$ & $0(0 \%)$ & $\begin{array}{l}10 \\
(16.39 \%)\end{array}$ & I (5.56\%) & $19(100 \%)$ & $0(0 \%)$ & $0(0 \%)$ & $0(0 \%)$ & $3(20 \%)$ & $\begin{array}{l}2 \\
(\mid 8.18 \%)\end{array}$ \\
\hline Ciprofloxacin & $\mathrm{R}$ & $0(0 \%)$ & $\begin{array}{l}8 \\
(15.09 \%)\end{array}$ & $\begin{array}{l}2 \\
(|1 .| 1 \%)\end{array}$ & $0(0 \%)$ & $0(0 \%)$ & $0(0 \%)$ & $0(0 \%)$ & $0(0 \%)$ & $\begin{array}{l}4 \\
(36.36 \%)\end{array}$ \\
\hline AMPICILLIN & $\mathrm{R}$ & $4(100 \%)$ & $\begin{array}{l}53 \\
(89.83 \%)\end{array}$ & $\begin{array}{l}14 \\
(87.5 \%)\end{array}$ & $\begin{array}{l}10 \\
(47.62 \%)\end{array}$ & $\begin{array}{l}4 \\
(57.14 \%)\end{array}$ & $12(80 \%)$ & 4 (100\%) & $9(45 \%)$ & $6(60 \%)$ \\
\hline Erythromycin & $\mathrm{R}$ & $\begin{array}{l}2 \\
(66.67 \%)\end{array}$ & $\begin{array}{l}29 \\
(48.33 \%)\end{array}$ & $0(0 \%)$ & $\begin{array}{l}\text { II } \\
\text { (47.83\%) }\end{array}$ & $0(0 \%)$ & $\begin{array}{l}8 \\
(57.14 \%)\end{array}$ & $3(75 \%)$ & $9(45 \%)$ & $\begin{array}{l}4 \\
(66.67 \%)\end{array}$ \\
\hline $\begin{array}{l}\text { Piperacillin/ } \\
\text { Tazobactam }\end{array}$ & $\mathrm{R}$ & $\begin{array}{l}\text { I } \\
(8.33 \%)\end{array}$ & $0(0 \%)$ & $0(0 \%)$ & - & $0(0 \%)$ & - & - & - & I (25\%) \\
\hline Amikacin & $\mathrm{R}$ & $0(0 \%)$ & - & - & $I(100)$ & $0(0 \%)$ & - & - & - & $0(0 \%)$ \\
\hline Chloramphenicol & $\mathrm{R}$ & $4(40 \%)$ & 4 (7.27\%) & $0(0 \%)$ & $0(0 \%)$ & $\begin{array}{l}\text { I } \\
\text { (16.67\%) }\end{array}$ & $0(0 \%)$ & $0(0 \%)$ & $0(0 \%)$ & $0(0 \%)$ \\
\hline Amox/Cla & $\mathrm{R}$ & $\begin{array}{l}\text { I } \\
\text { (33.33\%) }\end{array}$ & $\begin{array}{l}26 \\
(44.07 \%)\end{array}$ & I (5.56\%) & $6(30 \%)$ & $2(25 \%)$ & $\begin{array}{l}8 \\
(53.33 \%)\end{array}$ & 4 (100\%) & $\begin{array}{l}3 \\
\text { (I5.79\%) }\end{array}$ & $4(40 \%)$ \\
\hline Tetracycline & $\mathrm{R}$ & I (50\%) & $\begin{array}{l}19 \\
(44.19 \%)\end{array}$ & $\begin{array}{l}2 \\
\text { (11.76\%) }\end{array}$ & $6(30 \%)$ & $0(0 \%)$ & $\begin{array}{l}3 \\
(27.27 \%)\end{array}$ & I (25\%) & $\begin{array}{l}3 \\
(21.43 \%)\end{array}$ & I (50\%) \\
\hline Cefalexin & $\mathrm{R}$ & $2(50 \%)$ & $\begin{array}{l}26 \\
(42.62 \%)\end{array}$ & $\begin{array}{l}2 \\
\text { (II.76\%) }\end{array}$ & $10(50 \%)$ & I (20\%) & $\begin{array}{l}8 \\
(53.33 \%)\end{array}$ & $4(100 \%)$ & $\begin{array}{l}6 \\
(31.58 \%)\end{array}$ & $\begin{array}{l}5 \\
(62.5 \%)\end{array}$ \\
\hline Cefuroxime & $\mathrm{R}$ & $2(50 \%)$ & $\begin{array}{l}26 \\
(42.62 \%)\end{array}$ & I (5.56\%) & I (5\%) & I (20\%) & $\begin{array}{l}8 \\
(53.33 \%)\end{array}$ & $4(100 \%)$ & $\begin{array}{l}3 \\
(16.67 \%)\end{array}$ & $\begin{array}{l}5 \\
(55.56 \%)\end{array}$ \\
\hline Ceftriaxone & $R$ & $2(40 \%)$ & $\begin{array}{l}23 \\
(43.4 \%)\end{array}$ & $0(0 \%)$ & $0(0 \%)$ & $0(0 \%)$ & $6(50 \%)$ & $3(100 \%)$ & $\begin{array}{l}2 \\
(11.76 \%)\end{array}$ & $\begin{array}{l}\text { I } \\
\text { (II.II\%) }\end{array}$ \\
\hline Imipenem & $\mathrm{R}$ & $0(0 \%)$ & - & - & - & $0(0 \%)$ & - & - & - & $0(0 \%)$ \\
\hline Vancomycin & $R$ & $0(0 \%)$ & $0(0 \%)$ & $0(0 \%)$ & $0(0 \%)$ & $0(0 \%)$ & $0(0 \%)$ & $0(0 \%)$ & $0(0 \%)$ & $0(0 \%)$ \\
\hline
\end{tabular}

Abbreviations: Pa, Pseudomonas aeruginosa; Se, staphylococcus epidermidis; Sa, Staphylococcus aureus; Sp, Streptococcus pneumoniae; Mx, Moraxella sp; Sh, Staphylococcus hominis; MRSA, Methicillin-resistant Staphylococcus aureus; Gp, Gram Positive; Gn, Gram Negative; R, Resistant.

Staphylococcus epidermidis as the most common cause, while Streptococcus pneumoniae is the second, followed by Staphylococcus aureus. These results differ with one study carried out in the UAE that found Pseudomonas aeruginosa to be the most common causative organism. ${ }^{13}$ This discrepancy in the prevalence of the causative organism could be explained due to the low number of contact lens usage in our sample, which is known to be associated 
Table 4 Associations Between Risk Factors and Visual Acuity

\begin{tabular}{|l|l|l|l|l|}
\hline Risk Factors & Number & $\begin{array}{l}\text { VA First } \\
\text { Visit }\end{array}$ & $\begin{array}{l}\text { VA Last } \\
\text { Visit }\end{array}$ & P-value \\
\hline Contact lens & 7 & 0.56 & 0.01 & 0.062 \\
\hline Osd & 18 & 1.67 & 0.97 & 0.033 \\
\hline $\begin{array}{l}\text { Recent ocular } \\
\text { surgery }\end{array}$ & 24 & 2.43 & 2.38 & 0.483 \\
\hline Trauma & 41 & 2.16 & 2.01 & 0.389 \\
\hline $\begin{array}{l}\text { Diabetes } \\
\text { mellitus }\end{array}$ & 24 & 2.50 & 2.49 & 0.954 \\
\hline Topical steroid & 11 & 2.69 & 2.25 & 0.093 \\
\hline
\end{tabular}

with Pseudomonas aeruginosa. ${ }^{17,18}$ Our study shows that the most common site of bacterial infiltration is paracentral (45.9\%), Although another study showed that the most common infiltration site was central $(51.1 \%) .{ }^{16}$ Our study illustrates that the paracentral infiltration is most common for all organisms except for Staphylococcus hominis. All causative organisms of microbial keratitis are not often associated with the presence of hypopyon except in Streptococcus pneumoniae where hypopyon presence is estimated to be $52.94 \%$.

Visual outcomes after bacterial keratitis depend on several factors, such as the location, size, predisposing factors, and the causative organism. ${ }^{19}$ In our study, we looked at the effect of different predisposing factors on the visual outcomes, and we found that the presence of systemic diseases such as diabetes mellitus is associated with poor outcomes as well as a recent ocular surgery. This might be related to the fact that those patients tend to have poor visual baseline compared to normal individuals. Moreover, final VA improved for all cases except in cases caused by MRSA. This result is similar to a recent study conducted in Spain in which MRSA cases were associated with the worst prognosis. ${ }^{20}$ All isolates tested for vancomycin were sensitive, including 4 cases of MRSA. Other regional data offer the same result-that is, no organism showed resistance to vancomycin. ${ }^{16}$

Staphylococcus epidermidis is the most commonly isolated organism $(\mathrm{n}=61)$ and showed a high sensitivity rate for vancomycin [61 (100\%)], chloramphenicol [51 (92.73\%)], ofloxacin [45 (86.54\%)], ciprofloxacin [45 $(84.91 \%)]$, and gentamicin [51 (83.61\%)]. On the other hand, resistance to penicillin and ampicillin was found in $55(90 \%)$ and $53(89.83)$ cases, respectively.
The resistance pattern of Streptococcus pneumoniae to penicillin is higher in our study (54.55\%) compared to a previous study conducted in Riyadh $(31.9 \%){ }^{16}$ However, a study conducted in the USA showed a higher resistance to penicillin (64\%). ${ }^{21}$ Two previous studies were performed in Saudi Arabia and Australia and showed no resistance cases to ofloxacin; on the other hand, one case of Streptococcus pneumoniae was resistant to ofloxacin. Moreover, all cases tested for gentamicin were resistant. Similar to other previous studies, no cases were resistant to vancomycin, ceftriaxone, ciprofloxacin, and chloramphenicol. ${ }^{20,22}$

In our study, all cases of Staphylococcus aureus tested for erythromycin were sensitive $(100 \%)$, which is in contrast to studies done in the USA, Saudi Arabia, and Taiwan that found the resistance to erythromycin to be $67 \%, 18.6 \%$, and $88 \%$, respectively. $^{20,21,23}$ None of Staphylococcus aureus cases were resistant to chloramphenicol, which contrasts with the results from a previous study conducted in Australia that found a higher resistance rate $(21 \%){ }^{22}$ All cases of Staphylococcus aureus were tested for ceftriaxone, and they were all found to be sensitive to cefoxitin. While comparing the resistance pattern of Pseudomonas aeruginosa to ceftazidime, it was found to be $7.69 \%$ in our study, while it was around $5.6 \%$ in a previous national study. ${ }^{16}$ Pseudomonas aeruginosa is sensitive to several antibiotics such as tobramycin, ofloxacin, gentamicin, ciprofloxacin, amikacin, imipenem, and meropenem. This is in contrast to the result of another study that showed resistance patterns for gentamycin, ceftazidime, and ciprofloxacin to be $4.9 \%, 5.6 \%$, and $4.9 \%$, respectively. ${ }^{16}$ Moreover, a previous study conducted in Australia predicted the resistance for ciprofloxacin to be $7 \%{ }^{22}$

\section{Conclusion}

This work showed the common causative organisms, risk factors, and antibiotic profile of patients with bacterial keratitis in a tertiary hospital in Riyadh, Saudi Arabia. We found that the most common etiological organism of bacterial keratitis is staphylococcus epidermidis.

The results of our study might be helpful in clinical practice by aiding appropriate diagnosis and accurate management through the selection of the proper empirical therapy. For an accurate assessment of visual outcome, we recommend conducting a prospective study with a larger sample size. Choosing vancomycin empirically for Grampositive organisms with Tobramycin or Ceftazidime for the coverage of gram-negative organisms is recommended followed by modifying this regimen after the culture result. 


\section{Ethical Approval and Informed Consent}

This retrospective study was reviewed and approved by the institutional review board of King Saud University Hospital. The study adhered to the tenets of the Declaration of Helsinki. Since the data were anonymous and all patients had been told about possible research use of their data, informed consent had not been taken. All data were coded before analysis to ensure patient confidentiality. Only assigned staff had access to patient's information.

\section{Disclosure}

The authors report no conflicts of interest in this work.

\section{References}

1. Whitcher JP, Srinivasan M, Upadhyay MP. Corneal blindness: a global perspective. Bull World Health Organ. 2001;79(3):214-221.

2. Jayaraman K, Kalavathy CM, Pragya P, Jesudasan CAN, Thomas PA. Spectrum of bacterial keratitis at a tertiary eye care centre in Ind1. Wells VE, Deykin EY, Klerman GL. Risk factors for depression in adolescence. Psychiatr Dev. 1985;3(1):83-108. ia. BioMed Res Int. 2013;181564.

3. Al-Mujaini A, Al-Kharusi N, Thakral A, Wali UK. Bacterial keratitis: perspective on epidemiology, clinico-pathogenesis, diagnosis and treatment. Sultan Qaboos Univ Med J. 2009;9(2):184-195.

4. Schaefer F, Bruttin O, Zografos L, Guex-Crosier Y. Bacterial keratitis: a prospective clinical and microbiological study. $\mathrm{Br} \mathrm{J} \mathrm{Ophthalmol.}$ 2001;85(7):842-847. doi:10.1136/bjo.85.7.842

5. Pinna A, Zanetti S, Sotgiu M, Sechi LA, Fadda G, Carta F. Identification and antibiotic susceptibility of coagulase negative staphylococci isolated in corneal/external infections. Br J Ophthalmol. 1999;83(7):771LP- 773. doi:10.1136/bjo.83.7.771

6. Aldebasi YH, Aly SM, Ahmad MI, Khan AA. Incidence and risk factors of bacteria causing infectious keratitis. Saudi Med J. 2013;34 (11):1156-1160.

7. Green M, Apel A, Stapleton F. Risk factors and causative organisms in microbial keratitis. Cornea. 2008;27(1):22-27. doi:10.1097/ ICO.0b013e318156caf2

8. Afshari NA, Ma JJK, Duncan SM, et al. Trends in resistance to ciprofloxacin, cefazolin, and gentamicin in the treatment of bacterial keratitis. J Ocul Pharmacol Ther off J Assoc Ocul Pharmacol Ther. 2008;24(2):217-223. doi:10.1089/jop.2007.0085
9. Lap-Ki A, Kai-Wang K, Chi-Lai C, et al. Predisposing factors, microbial characteristics, and clinical outcome of microbial keratitis in a tertiary centre in Hong Kong: a 10-year experience. J Ophthalmol. 2015;2015(15):1-9.

10. Hedayati H, Ghaderpanah M, Rasoulinejad SA, Montazeri M. Clinical presentation and antibiotic susceptibility of contact lens associated microbial keratitis. J Pathog. 2015;2015:1-5. doi:10.1155/2015/152767

11. Manaviat MS. Epidemiology and outcome of corneal ulcer in Yazd Shahid Sadoughi Hospital. Acta Medica Iranica. 2004;136-141.

12. Bourcier T, Thomas F, Borderie V, Chaumeil C, Laroche L. Bacterial keratitis: predisposing factors, clinical and microbiological review of 300 cases. Br J Ophthalmol. 2003;87(7):834-838. doi:10.1136/bjo.87.7.834

13. Elhanan MM, Nabi A, Tayara F, Alsharhan M. Bacterial keratitis risk factors, pathogens and antibiotic susceptibilities: a 5-year review of cases at Dubai hospital, Dubai. J Clin Exp Ophthalmol. 2016;07 (04):1-5. doi:10.4172/2155-9570.1000591

14. Bukhari A, Ajlan R, Alsaggaf H. Prevalence of dry eye in the normal population in Jeddah, Saudi Arabia. Orbit. 2009;28(6):392-397. doi:10.3109/01676830903074095

15. Bataineh H, Hammory Q, Khatatba A. Bacterial keratitis: risk factors and causative agents. Sudan Jms. 2008;3(January2003):7-10.

16. Al-Dhaheri HS, Al-Tamimi MD, Khandekar RB, Khan M, Stone DU. Ocular pathogens and antibiotic sensitivity in bacterial keratitis isolates at King Khaled Eye Specialist Hospital, 2011 to 2014. Cornea. 2016;35(6):789-794. doi:10.1097/ICO.0000000000000844

17. Keay L, Radford C, Dart JK, Edwards K, Stapleton F. Perspective on 15 years of research: reduced risk of microbial keratitis with frequent-replacement contact lenses. Eye Contact Lens Sci Clin Pract. 2007;33(4):167-168. doi:10.1097/01.icl.0000248157.94115.7c

18. Woods CA, Jones DA, Jones LW, Morgan PB. A seven year survey of the contact lens prescribing habits of Canadian optometrists. Optom Vis Sci. 2007;84(6):505-510. doi:10.1097/OPX.0b013e318073c318

19. Miedziak AI, Miller MR, Rapuano CJ, Laibson PR, Cohen EJ. Risk factors in microbial keratitis leading to penetrating keratoplasty. Ophthalmology. 1999;106(6):1166-1171. doi:10.1016/S0161-6420(99) 90250-6

20. Mediero S, de Los Bueis AB, Spiess K, et al. Clinical and microbiological profile of infectious keratitis in an area of Madrid, Spain. Enfermedades Infecciosas Microbiologia Clinica (English Ed.). 2018;36(7):409-416. doi:10.1016/j.eimce.2017.08.015

21. Jin H, Parker WT, Law NW, et al. Evolving risk factors and antibiotic sensitivity patterns for microbial keratitis at a large county hospital. Br J Ophthalmol. 2017;101(11):1483-1487.

22. Watson S, Cabrera-Aguas M, Khoo P, et al. Keratitis antimicrobial resistance surveillance program, Sydney, Australia: 2016 annual report. Clin Exp Ophthalmol. 2018;25.

23. Hsiao CH, Sun CC, Yeh LK, et al. Shifting trends in bacterial keratitis in Taiwan: a 10-year review in a tertiary-care hospital. Cornea. 2016;35(3):313-317. doi:10.1097/ICO.00000000000000734
Clinical Ophthalmology

\section{Publish your work in this journal}

Clinical Ophthalmology is an international, peer-reviewed journal covering all subspecialties within ophthalmology. Key topics include: Optometry; Visual science; Pharmacology and drug therapy in eye diseases; Basic Sciences; Primary and Secondary eye care; Patient Safety and Quality of Care Improvements. This journal is indexed on PubMed
Central and CAS, and is the official journal of The Society of Clinical Ophthalmology (SCO). The manuscript management system is completely online and includes a very quick and fair peer-review system, which is all easy to use. Visit http://www.dovepress.com/ testimonials.php to read real quotes from published authors.

\section{Dovepress}

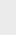

